\title{
Belajar dari Simeulue: Memahami Sistem Peringatan Dini Tsunami di Indonesia
}

\author{
Anis Kurniasih $^{1 *}$, Jenian Marin ${ }^{1}$, Reddy Setyawan ${ }^{1}$
}

${ }^{1}$ Departemen Teknik Geologi, Universitas Diponegoro, Jl. Prof. Soedharto Tembalang, Semarang

\begin{abstract}
Abstrak
Sistem peringatan dini tsunami tidak hanya menyangkut teknologi namun juga melibatkan kesiapsiagaan masyarakat sebagai komponen sosial budaya dan ekonomi politik yang perlu diidentifikasi dan diperbaiki. Masyarakat Simeulue mengangkat kearifan lokal "smong" sebagai sistem peringatan dini tsunami tradisional yang berhasil menyelamatkan mereka dari bencana. Sistem ini dapat diadaptasi dan diterapkan ke masyarakat di daerah lain yang rentan terhadap bencana yang sama. Dengan latar belakang tersebut, artikel ini disusun dengan tujuan untuk memahami dan menggali permasalahan dalam penerapan sistem peringatan dini tsunami di Indonesia melalui studi literatur. Data dan bahan diperoleh dari jurnal, prosiding, buku, majalah, wawancara dan laporan serta wawasan yang didapat saat tinjauan lapangan pada Ekspedisi Widya Nusantara tahun 2017. Hasil studi menunjukkan kesiapsiagaan terhadap gempa dan tsunami masih rendah sehingga ketika bencana terjadi masyarakat belum dapat melakukan penyelamatan secara mandiri. Belajar dari kearifan lokal masyarakat Simeulue melalui cerita smong yang dipahami sebagai sistem peringatan dini tsunami, saat ini kita membutuhkan sebuah metode pendekatan yang dapat diterima dengan mudah untuk meningkatkan kesiapsiagaan terhadap bencana. Contohnya dengan membuat program televisi atau animasi yang dapat ditonton semua kalangan. Dengan menampilkan program ini secara berkala, muatan tentang kesiapsiagaan terhadap tsunami (dan atau bencana lainnya) akan tertanam dalam memori sehingga mampu meningkatkan kesiapsiagaan penontonnya.
\end{abstract}

Kata kunci: Kesiapsiagaan masyarakat; sistem peringatan dini tsunami; Smong.

\begin{abstract}
The tsunami early warning systems do not only involve technology but also involve community awareness and preparedness as a socio-cultural and political economic component that needs to be identified and improved. The Simeuluean adopted the indigenous knowledge "smong" as a traditional tsunami early warning system that has saved them from disaster. This system can be adapted and applied to communities in other vulnerable areas. With this background, the authors composed this article with the aim to understand and explore the problems in the implementation of the tsunami early warning system in Indonesia through literature reviews. Data and materials were obtained from journals, proceedings, books, magazines, and reports as well as insights gained during the field survey on the Widya Nusantara Expedition in 2017. The results of the study show that earthquake and tsunami awareness was still low so that when a disaster occurred the community could not evacuate themselves independently. Learning from the indigenous knowledge of the Simeulue community through the smong story that is understood as a tsunami early warning system, we need approaches that can be easily applied to improve disaster preparedness. For example, by making television programs or animations. By displaying this program in national television or internet platform channel regularly, the content of tsunami preparedness (and or other disasters) will be embedded in memory so as to increase the awareness.
\end{abstract}

Keywords: Community preparedness; tsunami early warning system; Smong.

\section{PENDAHULUAN}

Badan Nasional Penanggulangan Bencana (BNPB) mencatat dalam kurun waktu 10 tahun antara 2005 hingga 2015 terjadi sekitar 3810 bencana yang merupakan bencana geologi. Bencana ini meliputi gempabumi, tsunami, letusan gunungapi, dan tanah longsor. Jumlah ini menyusun kurang lebih $22 \%$ dari total kejadian bencana alam yang terjadi pada periode waktu tersebut. Jika dilihat dari angka kejadiannya, bencana geologi tidak terlalu sering terjadi dibanding bencana alam lain. Namun jika dilihat

*) Korespondensi : anis.kurniasih@live.undip.ac.id 
dari dampak yang ditimbulkan, bencana geologi khususnya gempabumi dan tsunami memberikan dampak yang lebih besar (Amri dkk., 2016).

Berdasarkan hasil kajian risiko bencana oleh BNPB tahun 2015, diketahui bahwa jumlah jiwa yang terancam bahaya tsunami melebih 4 juta jiwa dan ancaman kerugian aset sebesar kurang lebih 71 triliun rupiah (Amri dkk., 2016). Dengan peningkatan jumlah penduduk Indonesia, maka jumlah jiwa yang terancam bahaya tsunami juga dipastikan mengalami peningkatan. Data BNPB menunjukkan tingginya angka korban jiwa pada gempabumi dan tsunami yang terjadi di wilayah perairan Selat Sunda dan Sulawesi pada 2018 lalu (Tabel 1).

Setelah tsunami 2004, Indonesia telah membangun sistem peringatan dini tsunami (Indonesian Tsunami Early Warning System Ina-TEWS) di bawah koordinasi Kementerian Riset dan Teknologi, dan dioperasikan oleh Badan Meteorologi Klimatologi dan Geofisika (BMKG). Jerman memberikan kontribusi pada pembangunan dan pengembangan Ina-TEWS yang meliputi sistem pemantauan, pengolahan dan analisis, penyebaran, pembangunan kapasitas, serta peningkatan kewaspadaan dan kesiapsiagaan masyarakat.

Tim kaji cepat bersama melakukan evaluasi sistem peringatan dini tsunami pada kejadian gempabumi dan tsunami Aceh 11 April 2012. Dalam laporannya disebutkan bahwa meskipun BMKG telah mengeluarkan peringatan tsunami, sirene tidak diaktifkan oleh pemerintah daerah sehingga 10 menit setelah peringatan, sirene diaktifkan oleh BMKG dari jarak jauh namun beberapa sirene tidak dapat diaktifkan. Evaluasi pada sistem menunjukkan buoy tsunami di perairan Aceh seluruhnya rusak sehingga tidak dapat mendeteksi perbedaan muka laut. Pengiriman data pasang surut dengan instrumen tide gauge mengalami keterlambatan kurang lebih 15 menit. Meskipun pada akhirnya gempa tersebut hanya memicu tsunami kecil dan tidak menimbulkan korban jiwa, hasil evaluasi menunjukkan bahwa sistem peringatan dini belum berjalan dengan baik (Tim Kaji Cepat Bersama, 2012).

Berdasarkan liputan media dan pernyataan $\mathrm{BMKG}$, sistem peringatan dini tsunami tidak berhasil mendeteksi tsunami pada 2018 di Palu sehingga menimbulkan banyak korban jiwa. Selain itu, verifikasi kejadian di Palu tidak dapat dilakukan karena tidak ada jalur telepon yang berfungsi di Palu sesaat setelah gempa terjadi. Terlepas dari gagalnya sistem peringatan, masyarakat juga dinilai belum memiliki gerakan refleks evakuasi mandiri begitu terjadi gempa (Lassa, 2018).

Melihat dua peristiwa tersebut, Ina-TEWS dinilai belum mampu memenuhi harapan yang diinginkan dalam meminimalkan timbulnya korban dan kerugian akibat tsunami. Selain itu, kesiapsiagaan masyarakat terhadap gempa dan tsunami tidak hanya menyangkut teknologi namun juga melibatkan komponen sosial budaya dan ekonomi politik yang perlu diidentifikasi dan diperbaiki.

Tim penulis dalam Ekspedisi Widya Nusantara tahun 2017 di Pulau Simeulue melakukan tinjauan lapangan untuk mengetahui sejarah tsunami di pulau tersebut. Dalam tinjauan lapangan, tim juga melakukan wawancara terhadap sejumlah penduduk yang tinggal di pesisir pantai untuk memperoleh informasi tentang kejadian tsunami. Hasil peninjauan lapangan dan wawancara menunjukkan bahwa tsunami pada akhir tahun 2004 dan awal tahun 2005 menimbulkan dampak kerusakan yang signifikan, namun tidak menimbulkan angka korban jiwa yang tinggi sebagaimana daerah lainnya. Masyarakat Pulau Simeulue mengenal tsunami dengan istilah "smong". Keberhasilan smong sebagai sistem peringatan dini tsunami tradisional telah membawa masyarakat Simeulue begitu dikenal oleh dunia dan mendapat penghargaan "United Nations Sasakawa Award for Disaster Reduction" pada tahun 2005.

Berdasarkan latar belakang tersebut, penulis menyusun artikel ini dengan tujuan untuk memahami dan menggali permasalahan dalam penerapan sistem peringatan dini tsunami di Indonesia. Belajar pada kearifan lokal masyarakat Pulau Simeulue, penulis juga ingin memberikan solusi atas permasalahan yang dihadapi dalam penerapan sistem peringatan dini tsunami di Indonesia dari sudut pandang sosial budaya.

Artikel ini disusun dengan tujuan untuk mendalami permasalahan yang dihadapi Indonesia dalam mempersiapkan diri menghadapi ancaman bahaya tsunami tidak hanya dalam hal teknologi namun juga dari sudut pandang sosial dan budaya masyarakat. 
Tabel 1. Data korban jiwa (meninggal dan hilang) akibat gempa dan tsunami tahun 2004-2019 (Statistik bencana, BNPB).

\begin{tabular}{|c|c|c|c|c|}
\hline No & Tahun & $\begin{array}{c}\text { Jumlah korban } \\
\text { meninggal dan hilang }\end{array}$ & Provinsi terdampak & Kategori bencana \\
\hline 1 & 2004 & 7 & Sumatera Barat & gempabumi \\
\hline 2 & & 33 & Nusa Tenggara Timur & gempabumi \\
\hline 3 & & 3 & Sulawesi tengah & gempabumi \\
\hline 4 & & 107 & Papua & gempabumi \\
\hline 5 & & 165791 & Aceh & tsunami \\
\hline 6 & & 154 & Sumatera Utara & tsunami \\
\hline 7 & 2005 & 62 & Aceh & gempabumi \\
\hline 8 & & 854 & Sumatera Utara & gempabumi \\
\hline 9 & 2006 & 493 & Jawa Barat & tsunami \\
\hline 10 & & 187 & Jawa Tengah & tsunami \\
\hline 11 & & 3 & DIY & tsunami \\
\hline 12 & & 1063 & Jawa Tengah & gempabumi \\
\hline 13 & & 4710 & DIY & gempabumi \\
\hline 14 & 2009 & 385 & Sumatera barat & gempabumi \\
\hline 15 & & 70 & Jawa Barat & gempabumi \\
\hline 16 & 2010 & 503 & Sumatera Barat & tsunami \\
\hline 17 & & 1 & Jawa Barat & gempabumi \\
\hline 18 & & 1 & Sulawesi Barat & gempabumi \\
\hline 19 & & 17 & Papua & gempabumi \\
\hline 20 & 2011 & 1 & papua & tsunami \\
\hline 21 & & 2 & Aceh & gempabumi \\
\hline 22 & & 1 & Sumatera Utara & gempabumi \\
\hline 23 & & 2 & Papua & gempabumi \\
\hline 24 & 2012 & 10 & Aceh & tsunami \\
\hline 25 & & 1 & Sumatera Barat & tsunami \\
\hline 26 & & 1 & Aceh & gempabumi \\
\hline 27 & & 5 & Sulawesi tengah & gempabumi \\
\hline 28 & 2013 & 45 & Aceh & gempabumi \\
\hline 29 & 2016 & 103 & Aceh & gempabumi \\
\hline 30 & 2017 & 2 & Jawa Barat & gempabumi \\
\hline 31 & & 1 & Jawa tengah & gempabumi \\
\hline 32 & & 1 & DIY & gempabumi \\
\hline 33 & & 1 & Maluku Utara & gempabumi \\
\hline 34 & 2018 & 128 & Lampung & tsunami \\
\hline 35 & & 325 & Banten & tsunami \\
\hline 36 & & 3474 & Sulawesi tengah & $\begin{array}{l}\text { gempabumi dan } \\
\text { tsunami }\end{array}$ \\
\hline 37 & & 562 & Nusa Tenggara barat & gempabumi \\
\hline 38 & 2019 & 4 & Nusa Tenggara barat & gempabumi \\
\hline
\end{tabular}

\section{METODOLOGI}

Artikel ilmiah ini ditulis melalui sebuah studi literatur. Studi literatur adalah sebuah metode penelitian yang dilakukan dengan hati-hati untuk memecahkan sebuah masalah dengan menggunakan data dan bahan dari perpustakaan 
yang dapat berupa buku, ensiklopedia, kamus, jurnal, dokumen, dan majalah (Khatibah, 2011; Harahap, 2014). Sumber pustaka yang digunakan meliputi dalam jurnal, prosiding, buku, majalah, dan laporan. Gambar-gambar kondisi pesisir Pulau Simeulue diperoleh dari tinjauan lapangan pada Ekspedisi Widya Nusantara tahun 2017. Pada saat tinjauan lapangan, tim juga mewawancara 5 orang yang ditemui di beberapa lokasi antara lain Desa Labuhan Bakti, Angkeu, Bunon, dan Sambay. Pertanyaan yang diajukan dalam wawancara tersebut antara lain:

1. Apakah anda mengetahui/menjadi saksi peristiwa tsunami di Simeulue pada tahun 2004 dan atau 2005?

2. Apakah anda mengetahui adanya korban jiwa pada peristiwa tersebut?

3. Apa yang anda ketahui tentang smong?

\section{HASIL DAN PEMBAHASAN}

Tulisan ini meliputi definisi sistem peringatan dini tsunami dan teknologi yang digunakan dalam perancangan sistem peringatan dini tsunami di Indonesia. Selain itu, sistem peringatan dini tsunami dari sudut pandang sosial dan budaya masyarakat dibahas dalam sub-bagian tersendiri.

\section{Teknologi Prakiraan Tsunami}

Tsunami memiliki panjang gelombang yang dapat mencapai ratusan kilometer. Di laut lepas, gelombang tsunami awalnya hanya memiliki amplitude sekitar $30-60 \mathrm{~cm}$, sehingga tidak terasa oleh kapal. Saat mencapai pantai, amplitude tsunami meningkat hingga mencapai 15 - 30 m karena perubahan kedalaman air. Gelombang ini bersifat sangat merusak dan jangkauannya dapat mencapai beberapa kilometer dari pantai sehingga menyebabkan kerusakan yang besar (Zhang dkk., 2009).

Peringatan dini tsunami merupakan sebuah mekanisme pengiriman pesan untuk memberitahukan masyarakat yang berada di dekat pantai terdampak tsunami tentang akan datangnya bahaya tsunami, tujuan dari peringatan ini adalah memberi waktu kepada autoritas lokal untuk mengambil tindakan penyelamatan. Semakin cepat dan tepat peringatan ini, maka tindakan penyelamatan akan semakin efektif.

Teknologi prakiraan tsunami telah banyak dikembangkan, salah satunya oleh Titov dkk. (2005). Mereka mengembangkan metode prakiraan tsunami dengan mengombinasikan data real-time tsunami dengan model numerik untuk menghitung intensitas bahaya dan waktu spesifik kejadian tsunami. Pemodelan dalam prakiraan tsunami ini kompleks dan rumit, selain itu juga memakan banyak waktu. Sementara itu, dalam peringatan dini tsunami, waktu yang tersedia untuk memberikan peringatan dari hasil prakiraan tersebut biasanya sangat pendek

Perjalanan gelombang tsunami dari laut lepas mencapai daratan memiliki waktu tempuh yang beragam. Sebagai contoh, gempa pemicu tsunami 2004 yang berjarak kurang lebih $160 \mathrm{~km}$ arah utara dari Pulau Simeulue pada $3,316^{\circ} \mathrm{N}$ dan $95,854^{\circ} \mathrm{E}$ kedalaman $30 \mathrm{~km}$ di bawah permukaan laut (Historical Tsunami Database, NOAA), mencapai daratan Aceh, Thailand, Srilangka dan Afrika dalam jangka waktu yang bervariasi. Berdasarkan observasi satelit, jarak antar gelombang pada tsunami tahun 2004 adalah 500 - $800 \mathrm{~km}$. Gelombang ini mencapai tinggi maksimum $0,6 \mathrm{~m}$ di laut terbuka namun bertambah menjadi sangat tinggi mencapai hampir $50 \mathrm{~m}$ mendekati perairan dangkal hingga pantai. Tsunami menerjang bagian utara Sumatra dalam waktu sangat singkat, dan 90 menit hingga dua jam kemudian mencapai Sri Lanka dan perairan timur India. Meskipun Thailand berjarak relatif dekat dengan pusat gempa, gelombang tsunami mencapai daerah tersebut setidaknya setelah dua jam dari terjadinya gempa, diduga karena tsunami berjalan lebih pelan di perairan Andaman. Tujuh jam kemudian gelombang tsunami mencapai wilayah perairan timur laut Somalia, Afrika (Timeline of the 2004 Indian Ocean Earthquake).

Zhang dkk. (2009) melakukan perhitungan sesuai dengan prinsip panjang gelombang pada perairan dangkal pada beberapa data kejadian tsunami termasuk tsunami 2004. Perkiraan waktu datangnya tsunami pada beberapa lokasi dibandingkan dengan data kejadian tsunami dan diperoleh kesimpulan bahwa perhitungan tersebut akurat dalam memprediksi waktu kedatangan tsunami. Konsep yang dikemukakan oleh Zhang dkk. (2009) hanya membutuhkan beberapa parameter dalam perhitungan, sesuai dengan rumus dasar untuk menghitung panjang gelombang (Persamaan 1 dan 2). Sehingga metode ini diklaim memiliki beberapa keunggulan antara lain dapat memprediksi waktu kejadian tsunami dengan cepat dan akurat. 
$c=\lambda / T$

$c=\sqrt{g h}$

Ket.

$\mathrm{c}=$ kecepatan gelombang

$\lambda=$ panjang gelombang

$\mathrm{T}=$ waktu

$\mathrm{g}=$ percepatan gravitasi

Persamaan 1 digunakan untuk menghitung kecepatan gelombang pada perairan dengan kedalaman air yang lebih kecil daripada panjang gelombang. Sedangkan persamaan 2 digunakan pada perairan dengan kedalaman yang lebih besar daripada panjang gelombang yang merambat.

\section{Sistem Peringatan Dini Tsunami di Indonesia}

Setelah gempa dan tsunami besar tahun 2004, perhatian dunia tertuju pada Indonesia. InaTEWS dengan kontribusi teknis dari Jerman telah mengembangkan proyek GITEWS (GermanIndonesian Cooperation for Tsunami Early Warning) yang berfokus pada penyusunan prosedur dan mekanisme untuk memastikan bahwa penduduk di daerah berisiko tsunami mendapatkan peringatan tepat waktu dan mampu melakukan upaya penyelamatan dengan cepat dan tepat. Teknologi yang dikembangkan dalam proyek GITEWS memadukan jaringan pemantauan seismologi dan geodesi untuk pengamatan gempa bumi dan tsunami melalui pengukuran dengan real-time GPS di samudera dan pengamatan satelit (Gambar 1.). Dalam pelaksanaannya, proyek ini memilih beberapa daerah percontohan yakni Padang, Bali, Bantul, Kebumen dan Cilacap, serta Ciamis dan Purworejo. Proyek GITEWS kemudian dilanjutkan dengan proyek PROTECTS (The Project for Training, Education and Consulting for Tsunami Early Warning Systems). Proyek ini merupakan bagian dari tindak lanjut proyek sebelumnya dengan menyediakan pendidikan, pelatihan dan saran ilmiah kepada pemangku jabatan dan masyarakat. Tujuan utama dari proyek ini antara lain untuk mendukung pemeliharaan sistem sensor dan perangkat keras serta penyempurnaan sistem infrastruktur dan proses pada sistem peringatan tsunami nasional di BMKG Jakarta.

Dalam proyek tersebut, Lauterjung dkk. (2010) mengungkapkan bahwa tsunami yang terjadi di Indonesia masuk dalam kategori near- field tsunami atau tsunami jarak dekat/lokal, yang berarti tsunami yang terjadi berjarak kurang lebih $200 \mathrm{~km}$ dari episenter gempa. Tsunami lokal dapat disebabkan oleh gempabumi, longsor bawah laut, atau letusan gunungapi. Waktu tiba tsunami lokal sangat singkat yakni 10 menit hingga 1 jam, sehingga penyebaran informasi peringatan dini tsunami menjadi sangat sulit. Dalam kasus ini, sistem peringatan dini tsunami mengharuskan diketahuinya posisi episenter gempa dan bidang deformasi yang terbentuk akibat gempa, secara cepat dan akurat. Sehingga tantangan utama dalam menyusun sistem peringatan dini tsunami di Indonesia adalah bagaimana mengetahui karakter zona deformasi yang terbentuk oleh gempa secara detil dan tepat. Selain itu, karakterisasi ini harus dilakukan secepat mungkin (5 - 10 menit setelah gempa). Parameter gempa seperti lokasi, kedalaman dan kekuatan gempa dapat diperoleh dalam waktu 2 4 menit. Sehingga sering kali episenter gempa tidak bisa langsung diidentifikasi segera setelah gempa terjadi, dan tidak jarang dalam penentuan kedalaman dan lokasi terjadi kesalahan hingga sejauh $50 \mathrm{~km}$ dari lokasi sebenarnya.

Proyek GITEWS menerapkan metode realtime GPS deformation monitoring atau pemantauan bidang deformasi menggunakan GPS secara real-time. Metode ini dinilai efektif dalam mendeteksi deformasi dengan dimensi beberapa sentimeter hingga meter dan jarak hingga ratusan kilometer dari pusat gempa. Informasi ini dapat diperoleh setidaknya dalam waktu 5-10 menit setelah gempa dan dapat segera digunakan untuk mendeteksi potensi terjadinya tsunami akibat gempa. Dalam proyek ini stasiun pemantauan tsunami dipasang di sejumlah lokasi di sepanjang pesisir pantai Samudera Hindia. Instalasi ini sangat penting karena dari sini informasi tentang ancaman bahaya tsunami pertama kali diperoleh. Data seismisitas dari tiap stasiun dikirimkan secara real-time melalui satelit ke pusat peringatan BMKG di Jakarta dan dianalisis dengan perangkat lunak SeisCompP3 (Lauterjung dkk., 2010; BMKG, 2012).

Ina-TEWS merupakan teknologi pemantauan dan pendeteksi yang mengombinasikan data seismisitas, data muka laut (sea-level monitoring) dan permukaan tanah (land/geodetic monitoring). Data geodetik dan oseanografi yang diperoleh dari beberapa stasiun geodetik yang terpasang di sepanjang pesisir dan GPS pelampung (GPS 
buoys) yang terpasang di laut. Skema jaringan yang digunakan dalam sistem peringatan dini tsunami dalam proyek GITEWS dapat diamati pada Gambar 1.

Perangkat lunak lain yang digunakan dalam sistem peringatan dini tsunami di Indonesia adalah DSS (Decision Support System). Perangkat ini digunakan untuk membantu petugas di pusat nasional peringatan dini tsunami (BMKG Jakarta) mengambil keputusan dan menghasilkan peringatan dini tsunami secara akurat dan cepat. Selain itu program ini dapat membantu mereka dalam menentukan lokasi yang mungkin terkena dampak tsunami, tingkat peringatan, dan waktu kedatangan tsunami (BMKG, 2012).

Setelah data diproses dan informasi tentang ancaman tsunami diperoleh, BMKG akan mengirimkan informasi kepada pemerintah daerah untuk selanjutnya disebarkan kepada masyarakat (Gambar 2). Dalam proses penyebaran informasi ini, penentu keberhasilannya adalah waktu. Semakin cepat informasi sampai kepada masyarakat, maka waktu yang tersedia untuk menyelamatkan diri pun akan semakin panjang. Selain itu, instruksi dari instansi terkait dalam proses evakuasi sangat diperlukan untuk menghindari kekacauan yang diakibatkan oleh kepanikan. Skema peringatan tsunami yang digunakan saat ini dapat diamati pada Gambar 3.
Dalam penyebaran berita peringatan, BMKG akan mengeluarkan empat tahapan berita mulai dari terjadinya gempabumi sampai berakhirnya ancaman tsunami (BMKG, 2012), yaitu (1) Berita 1: memuat parameter gempabumi dan perkiraan dampak tsunami yang digambarkan dalam tiga status ancaman (awas, siaga, dan waspada. (2) Berita 2: tambahan informasi mengenai parameter gempabumi dan status ancaman pada berita 1 serta perkiraan waktu tiba tsunami di pantai. (3) Berita 3: berisi hasil observasi tsunami dan perbaikan status ancaman yang diperoleh dari hasil pengamatan tsunami di stasiun pengukuran pasang-surut, GPS pelampung, CCTV dan radar tsunami. (4) Berita 4: berisi peringatan dini tsunami telah berakhir.

\section{Cerita Smong: Sebuah Kearifan Lokal}

Borrero dkk. (2011) melakukan survei lapangan pasca tsunami Maret 2005 yang melanda Nias dan Simeulue, tiga bulan setelah tsunami 2004. Meskipun tidak ada korban jiwa pada gempa dan tsunami 2005, Borrero dkk. (2011) menyebutkan bukti terjadinya gempa dan tsunami teramati di beberapa bagian pulau. Bagian paling selatan pulau di daerah Labuhan Bakti dijelaskan mengalami pengangkatan kurang lebih 1,4 $\mathrm{m}$ dan beberapa bangun rusak akibat terjangan tsunami setinggi $2,5 \mathrm{~m}$ yang menggenang hingga $300 \mathrm{~m}$ dari pantai. Tim penulis juga mengamati hal tersebut pada saat melakukan peninjauan lapangan di 2017 silam (Gambar 4).



Gambar 1. Jaringan dalam sistem peringatan dini tsunami yang dikembangkan melalui proyek GITEWS (Lauterjung dkk., 2010). 


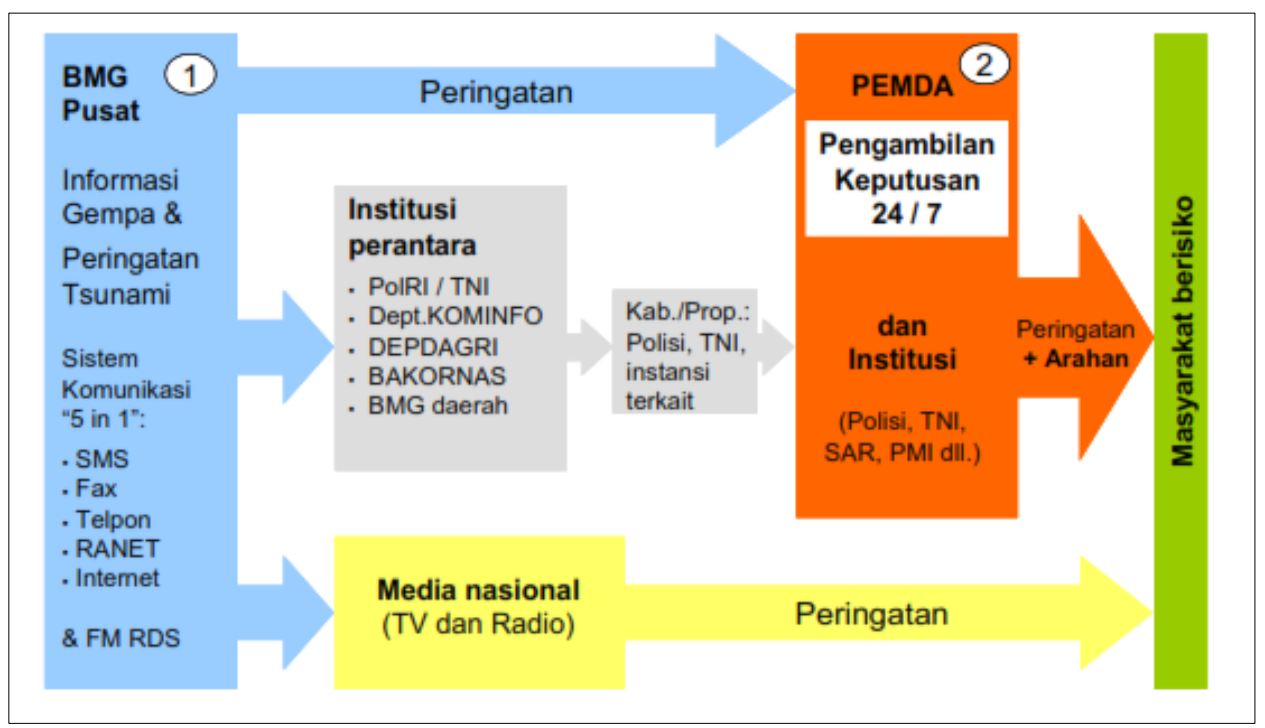

Gambar 2. Informasi dan rantai peringatan dini tsunami dari tingkat nasional ke daerah (GTZ, 2009)

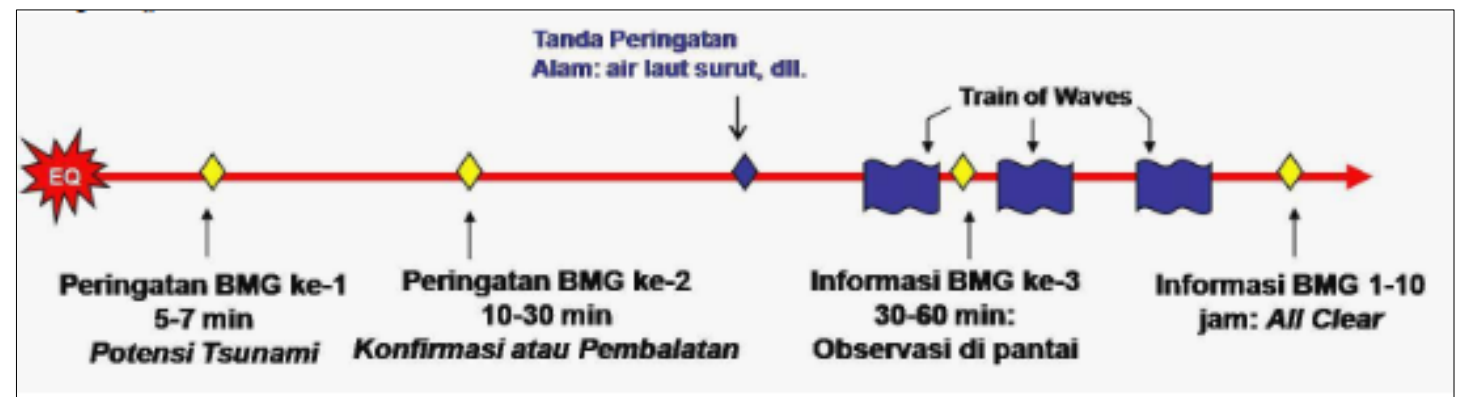

Gambar 3. Skema peringatan dini tsunami dimulai dari terjadinya gempa hingga pesan "Semua Aman". Waktu yang ditampilkan dapat berbeda-beda (GTZ, 2009).

Dalam survei lapangan tersebut, mereka juga melakukan wawancara kepada sejumlah korban termasuk diantaranya masyarakat Simeulue. Berdasarkan hasil wawancara tersebut, Borrero dkk. (2011) mengungkapkan bahwa cerita dan kearifan lokal yang dipercaya masyarakat Simeulue menjadi satu sistem peringatan dini tsunami yang terbukti berhasil menyelamatkan masyarakat Simeulue dari kedua bencana tsunami tersebut (Desember 2004 dan Maret 2005).

Masyarakat Simeulue mengenal tsunami dengan istilah "smong". Smong merupakan kearifan lokal atau Indigenous Knowledge (IK) yang dipercaya oleh masyarakat Simeulue dan pulau kecil di sekitarnya. Smong dipahami oleh masyarakat Simeulue sebagai sebuah fenomena alam berupa gelombang besar dari laut yang timbul setelah gempa besar. Pertanda akan datangnya smong dapat diamati dari surutnya air laut sesaat setelah gempa besar diikuti dengan suara gemuruh yang terdengar keras. Saat pertanda ini muncul, mereka diajarkan untuk menyelamatkan diri dengan menjauhi daerah pantai dan menuju dataran yang tinggi seperti puncak bukit. Pertanda ini telah dipahami dengan baik oleh masyarakat Simuelue berdasarkan cerita dari orang tua ataupun kakek-nenek mereka. Cerita ini disampaikan secara turun temurun melalui manafi-nafi (cerita daerah), mananga-nanga (lagu pengantar tidur), dan nandong (senandung). Lirik dan isi dari lagu dan senandung sebagai sarana penyaluran cerita smong secara dramatis menjelaskan detik-detik terjadinya smong, pertanda yang muncul, dan tindakan yang harus segera dilakukan ketika pertanda tersebut muncul (Syafwina, 2014; Gadeng dkk., 2018; Suciani dkk., 2018; Gadeng dkk., 2019; Sutton dkk., 2020).

Syafwina (2014) menulis berdasarkan hasil wawancaranya terhadap responden yang tinggal di Banda Aceh, Aceh Besar, dan Simeulue saat tsunami tahun 2004 terjadi. Syafwina (2014) mengemukakan bahwa setelah gempa besar terjadi, warga Simeulue serentak meneriakkan "Smong" sambil berusaha menyelamatkan diri ke 




Gambar 4. (A) Kenampakan pantai yang mengalami pengangkatan akibat gempa 2004 dan 2005 di pesisir selatan Pulau Simeulue, (B) bagian terumbu karang yang terangkat hingga $1,5 \mathrm{~m}$ dari permukaan air laut.

tempat yang tinggi. Diungkapkan pula bahwa keberhasilan cerita smong dalam menyelamatkan masyarakat Simeulue saat tsunami 2004 merupakan sistem peringatan dini tsunami secara tradisional yang dapat mengurangi dampak bencana (Disaster Risk Reduction/ DRR). Hasil wawancara Syafwina (2014 tersebut sejalan dengan hasil wawancara tim penelitian ini yang mengungkapkan bahwa masyarakat mengenal tsunami sebagai smong.

Rahman dkk. (2017) mengadakan penelitian etnografi tentang bagaimana kearifan lokal smong diterima, dipahami, dan disampaikan oleh pelaku sejarah kejadian tsunami 1907 kepada masyarakat Simeulue yang menghadapi tsunami 2004. Menurutnya pemahaman cerita smong oleh masyarakat Simeulue dan bagaimana cerita itu disampaikan secara turun temurun menjadi kunci berfungsinya smong sebagai sistem peringatan dini tsunami di Simeulue. Sehingga kini istilah smong tak lagi hanya dipahami sebagai cerita atau lagu pengantar tidur saja, namun telah menjadi kode penyelamatan diri.

\section{Sistem Peringatan Dini dan Evakuasi}

Løvholt dkk. (2014) mengemukakan bahwa faktor penentu keberhasilan sebuah sistem peringatan dini dan proses evakuasi adalah tersedianya akses menuju tempat yang aman, penggunaan sarana peringatan yang efektif (jaringan komunikasi), dan respon tindakan penyelamatan oleh korban (tidak panik dan mengetahui langkah evakuasi yang tepat).

Sistem peringatan dini tsunami yang dimiliki oleh Indonesia telah maju. Data dan informasi terkini gempa dan potensi tsunami pun dapat diakses secara online (Ina-TEWS.bmkg.go.id) oleh siapapun dan kapanpun. Akses dan informasi jalur evakuasi juga telah terinstalasi dengan baik di lokasi berpotensi tsunami. Akan tetapi, data menunjukkan bahwa tsunami selalu menimbulkan korban jiwa yang tinggi (Tabel 1). Komponen teknis dalam usaha mengurangi dampak bencana tsunami sebenarnya telah banyak dilakukan baik oleh Indonesia maupun negara lain. Komponen teknis tersebut meliputi pengembangan dan peningkatan kualitas sistem peringatan dini tsunami yang telah ada, perencanaan evakuasi, dan pemetaan jalur evakuasi. Namun komponen sosial belum banyak dieksplorasi sebagai komponen yang penting dalam menunjang usaha tersebut. Dari sudut pandang sosial, aspek penilaian kerentanan terhadap bencana berfokus pada manusia, kecenderungan tingkah laku dan proses sosial yang berpengaruh kepada terpaparnya suatu komunitas terhadap bencana. Sebagai contoh kerentanan sosial terhadap bencana adalah dengan melihat angka korban meninggal dan hilang oleh tsunami di Indonesia.

Sebagai usaha meningkatkan kapasitas kesiapsiagaan tsunami, proyek PROTECT telah melakukan banyak upaya. Diantaranya adalah mengadakan pelatihan dan simulasi fasilitator tanggap tsunami (FaTmi) dan kader tanggap tsunami (KaTsumi). Kegiatan tersebut telah menjangkau komponen masyarakat hingga tingkat desa dan rumah tangga. Namun keberhasilan program tersebut tampaknya belum menunjukkan keberhasilan yang menonjol.

Data statistik korban jiwa (meninggal atau hilang) pada tsunami 2004 menunjukkan bahwa korban terbanyak berasal dari golongan wanita, anak-anak dan orang dewasa berumur di atas 60 tahun. Korban jiwa wanita $(55,9-74,6 \%)$ 
berjumlah lebih besar 1,9 kali daripada korban jiwa laki-laki $(28,8-42,7 \%)$. Sementara itu, korban jiwa usia anak $(0-9$ tahun) berjumlah $21,1 \%$ dan orang dewasa berusia di atas 60 tahun berjumlah 28\% (Rofi dkk., 2006). Hal ini menunjukkan golongan yang paling rentan terhadap bahaya tsunami adalah wanita, anakanak, dan lansia. Penjelasan paling mungkin diterima terkait dengan penyebab tingginya angka kematian pada golongan tersebut adalah karena golongan tersebut memiliki kemampuan penyelamatan yang lebih rendah dibandingkan golongan lainnya.

Peluang untuk selamat dari ancaman bahaya tsunami jarak dekat sangat tergantung pada kapasitas individu. Kapasitas ini tidak hanya dinilai dari kemampuan fisik saja namun juga dari kemampuan menilai situasi dengan cepat dan mengambil keputusan serta tindakan yang tepat. Kemampuan tersebut didasari oleh pengetahuan individu yang cukup tentang ancaman bahaya tsunami dan rencana kesiapsiagaan di masingmasing daerah. Sehingga ketika sistem peringatan dan arahan tidak berfungsi sebagaimana mestinya, mereka masih mampu bereaksi dengan benar (Spahn dkk., 2010).

Belajar dari kearifan lokal masyarakat Simeulue, cerita smong telah dipahami sebagai sistem peringatan dini tsunami. Mereka dapat menilai situasi dengan cepat dan mengambil tindakan penyelamatan dengan tepat pada saat terjadi gempa besar yang berpotensi memicu tsunami. Nilai-nilai cerita smong dapat dipahami dan diterapkan dengan baik oleh masyarakat Simeulue karena hal ini telah menjadi bagian kehidupan yang dituturkan setiap hari. Berkaca dari hal tersebut, maka penting untuk menyediakan media edukasi yang sesuai dengan budaya masyarakat setempat tentang risiko bahaya tsunami dan langkah evakuasi yang tepat. Anak-anak Simeulue mengetahui cerita smong yang disampaikan oleh orang tua atau kakek nenek mereka, dan ketika dewasa mereka masih memahaminya dengan baik sehingga saat tsunami datang, memori tersebut berhasil menyelamatkan mereka.

Jika proses penuturan ini kita adaptasi dan terapkan di daerah lain bukan tidak mungkin hal ini akan mampu mengurangi risiko terhadap bencana. Tidak harus melalui media yang sama seperti halnya cerita smong yang disalurkan dengan puisi, nyanyian, dan cerita pengantar tidur, media masa kini juga dapat digunakan.
Contohnya dengan membuat program televisi atau animasi yang dapat ditonton semua kalangan. Dengan menampilkan program ini secara berkala, muatan tentang kesiapsiagaan terhadap tsunami (dan atau bencana lainnya) akan tertanam dalam memori sehingga mampu meningkatkan kesiapsiagaan penontonnya.

\section{KESIMPULAN}

Indonesia telah memiliki sistem peringatan dini tsunami (Ina-TEWS) yang dikembangkan melalui proyek GITEWS (German-Indonesian Cooperation for Tsunami Early Warning) yang berfokus pada penyusunan prosedur dan mekanisme untuk memastikan bahwa penduduk di daerah berisiko tsunami mendapatkan peringatan tepat waktu dan mampu melakukan upaya penyelamatan dengan cepat dan tepat. Evaluasi sistem tersebut menunjukkan bahwa Ina-TEWS belum mampu memenuhi harapan yang diinginkan dalam meminimalkan timbulnya korban dan kerugian akibat tsunami. Kesiapsiagaan masyarakat terhadap gempa dan tsunami masih sangat rendah sehingga ketika bencana terjadi mereka belum dapat melakukan penyelamatan secara tepat dan cepat. Belajar dari kearifan lokal masyarakat Simeulue melalui cerita smong yang telah dipahami sebagai sistem peringatan dini tsunami, kita membutuhkan sebuah metode pendekatan sosial budaya untuk meningkatkan kesiapsiagaan masyarakat terhadap bencana dalam hal ini tsunami.

\section{UCAPAN TERIMA KASIH}

Terima kasih diucapkan kepada para peneliti di Pusat Penelitian Geoteknologi LIPI pada kegiatan Ekspedisi Widya Nusantara 2017.

\section{DAFTAR PUSTAKA}

Amri, M.R., Yulianti, G., Yunus, R., Wiguna, S., Adi, A.W., Ichwana, A.N., Randongkir, R.E., Septian, R.T., 2016. Risiko Bencana Indonesia (RBI). BNPB.

BMKG, 2012. Pedoman Pelayanan Peringatan Dini Tsunami Ina-TEWS-Edisi Kedua. BMKG.

Borrero, J.C., McAdoo, B., Jaffe, B., Dengler, L., Gelfenbaum, G., Higman, B., Hidayat, R., Moore, A., Kongko, W., Lukijanto, Peters, R., Prasetya, G., Trrov, V., Yulianto, E., 2011. Field Survey of the March 28, 2005 Nias- 
Simeulue Earthquake and Tsunami. Pure and Applied Geophysics, 168, hal. 1075 - 1088.

Gadeng, A.N., maryani, E., Rohmat, D., 2018. The Value of Local Wisdom Smong in Tsunami Disaster Mitigation in Simeulue Regency, Aceh Province. IOP Conf. Series: Earth and Environmental Science, 145, hal. 1 -6 .

Gadeng, A.N., Maryani, E., Ningrum, E., 2019. The simulation of Smong in geography learning to enhance understanding of disaster. IOP Conf. Series: Earth and Environmental Science, 286, hal. $1-8$.

GTZ, 2009. Konsep dan Rekomendasi untuk Implementasi Sistem Peringatan Dini Tsunami di Bali. GTZ-IS.

Harahap, N., 2014. Penelitian Kepustakaan. Jurnal Iqra ', 08, hal. 68-73.

Historical Tsunami Database, NOAA, https://www.ngdc.noaa.gov/hazard/tsu_db.sh tml, diakses tanggal 6 - 13 Januari 2020.

Khatibah, 2011. Penelitian Kepustakaan. Jurnal Iqra', 05, hal. 36 - 39 .

Lassa, J.A., 2018. Meninjau ulang strategi peringatan dini tsunami di Indonesia: cermin dari Palu. https://theconversation.com/au, diakses tanggal 13 Januari 2020.

Lauterjung, J., Münch, U., Rudloff, A., 2010. The challenge of installing a tsunami early warning system in the vicinity of the Sunda Arc, Indonesia. Natural hazards Earth System Sciences, 10, hal. 641 - 646.

Løvholt, F., Setiadi, N.J., Birkman, J., harbitz, C.B., Bach, C., Fernando, N., Kaiser, G., Nadim, F., 2014. Tsunami risk reduction - are we better prepared today than in 2004?. International Journal of Disaster Risk Reduction, 10, hal. 127 - 142.

Rahman, A., Sakurai, A., Munadi, K., 2017. The analysis of the development of the Smong story on the 1907 and 2004 Indian Ocean tsunamis in strengthening the Simeulue island community's resilience. International Journal of Disaster Risk Reduction, 29, hal. 1 -11 .
Rofi, A., Doocy, S., Robinson, C., 2006. Tsunami mortality and displacement in Aceh province, Indonesia. Disasters, 30, hal. 340 - 350.

Spahn, H., Hoppe, M., Vidiarina, H.D., Usdianto, B., 2010. Experience from three years of local capacity development for tsunami early warning in Indonesia: challenges, lessons, and the way ahead. Natural Hazards and Earth System Sciences, 10, hal. 1411 - 1429.

Statistik Bencana, BNPB, https://bnpb.cloud/dibi/, diakses tanggal 6 13 Januari 2020.

Suciani, A., Islami, Z.R., Zainal, S., Sofiyan, Bukari, 2018. "Smong" as local wisdom for disaster risk reduction. IOP Conf. Series: Earth and Environmental Science, 148, hal. 1 -7 .

Sutton, S.A., Paton, D., Buergelt, P., Meilianda, E., Sagala, S., 2020. What's in name? "Smong" and the sustaining of risk communication and DRR behaviours as evocation fades. International Journal of Disaster Risk Reduction, 44, hal. 1 - 10.

Syafwina, 2014. Recognizing Indigenous Knowledge for Disaster Management: Smong, Early Warning System from Simeulue Island, Aceh. Procedia Environmental Sciences, 20, hal. 573 - 582.

Tim Kaji Cepat Bersama, 2012. Evaluasi Sistem Peringatan Dini Tsunami pada Kejadian Gempabumi dan Tsunami Aceh 11 April 2012. GIZ-IS PROTECTS.

Timeline of the 2004 Indian Ocean Earthquake, Wikipedia.

https://en.wikipedia.org/wiki/Timeline_of_the _2004_Indian_Ocean_earthquake, diakses tanggal 6 Januari 2020.

Titov, V.V., González, F.I., Bernard, E.N., Eble, M.C., Mofjeld, H.O., Newman, J.C., Venturato, A.J., 2005. Real-Time Tsunami Forecasting: Challenges and Solutions. Natural Hazards, 35, hal. 1 - 16.

Zhang, D.H., Yip, T.L., Ng, C-O., 2009. Predicting tsunami arrivals: Estimates and policy implications. Marine Policy, 33, hal. $643-650$. 